\title{
Why corporate venture capital funds fail - evidence from the European energy industry
}

\section{Tarja Teppo}

Cleantech Invest $\mathrm{Oy}$, Annankatu 25, FIN-00100 Helsinki, Finland

E-mail: tarja.teppo@cleantechinvest.com

\section{Rolf Wüstenhagen*}

\author{
Institute for Economy and the Environment (IWÖ-HSG), \\ University of St. Gallen, \\ Tigerbergstrasse 2, CH-9000 St. Gallen, Switzerland \\ E-mail: rolf.wuestenhagen@unisg.ch \\ *Corresponding author
}

\begin{abstract}
Corporate venture capital (CVC) is an important concept for large firms to manage innovation. CVC has been pioneered by major companies in the information technology, telecommunications and pharmaceutical industries. In 1999-2001, many large energy companies had launched CVC funds. In the most recent past, however, many energy companies have discontinued their activities, leading to what might be called the 'sudden death syndrome' of CVC in this industry. Our qualitative research suggests that one factor that has played an important role in the failure of CVC funds, and has largely been overlooked in previous research, is parent firm organisational culture. We develop a conceptual model that explains the relationship between organisational culture and CVC fund survival, including the moderating roles of decision-making practices in organisations and parent firm skills in managing and measuring success. Our findings are based on 27 qualitative in-depth interviews with corporate and independent VCs in the energy industry.
\end{abstract}

Keywords: corporate venturing; innovation management; venture capital; sustainable development; entrepreneurship; renewable energy; climate change.

Reference to this paper should be made as follows: Teppo, T. and Wüstenhagen, R. (2009) 'Why corporate venture capital funds fail - evidence from the European energy industry', World Review of Entrepreneurship, Management and Sustainable Development, Vol. 5, No. 4, pp.353-375.

Biographical notes: Tarja Teppo has completed her dissertation in 2006 at Helsinki University of Technology (HUT), Department of Industrial Engineering and Management, on the role of venture capital for Cleantech market creation. She previously worked in the corporate venturing division of a major telecommunications company in Finland and the USA. In 2005, she co-founded Cleantech Invest Oy, that operates a cleantech seed fund and provides cleantech investment advisory services in the Nordic market. Her main research interests are sustainable entrepreneurship, venture capital and corporate venturing.

Rolf Wüstenhagen is the Good Energies Professor for Management of Renewable Energies at the University of St. Gallen and Director of the Institute for Economy and the Environment (IWÖ-HSG). He has been a Visiting 
Professor at the University of British Columbia in Vancouver, Canada, and Copenhagen Business School, Denmark, in 2005 and 2008. He teaches corporate sustainability and energy management. His research focuses on consumer, investor and policy decisions related to renewable energy. Prior to pursuing an academic career, he has worked with one of the leading European energy venture capital funds.

\title{
1 Introduction
}

\begin{abstract}
"The first thing to ask is: Which CVC funds have been able to stay in existence for ten years or longer? There are not that many that have been around for very long. This tends to be a very cyclical kind of a mechanism. Many, many companies started programs and then got rid of them." (Henry Chesbrough, UC Berkeley) ${ }^{1}$
\end{abstract}

Corporate venture capital (CVC) funds are an important means for large firms to engage in innovation. However, academic literature as well as practical experience has provided ample evidence of the challenging nature of operating a CVC fund within a large incumbent organisation. Venture capital researchers have demonstrated that CVC funds are volatile (Gompers and Lerner, 2001) and varying in success (Sykes, 1986; Siegel et al., 1988; Gompers and Lerner, 1998; Chesbrough, 2000). We argue that the understanding of CVC can be enhanced by answering the following research question: How does parent firm organisational culture affect the survival of a CVC fund?

We investigate this research question in the context of an industry in which large, incumbent organisations are particularly relevant, and in which the need for innovation is increasingly acknowledged due to a variety of drivers: the energy industry. The energy industry is one of the largest sectors of the economy, and a number of environmental and geopolitical concerns, as well as new technological opportunities, have recently sparked interest in energy innovation. As a consequence, there is an increasing appetite in the venture capital community for investments in new, cleaner energy technologies. This has been mirrored by several large energy companies initiating CVC activities in the early years of this decade.

Our study on energy sector CVC funds is motivated by the fact that most of the previous studies on CVC have focused on industries that have experienced a 'venture capital glut' such as internet and communications technologies. Venturing in new energy technologies has received only scant attention from academic researchers. This is in stark contrast to the frequent coverage of venture capital investments in new energy and other clean technology firms in the business press (e.g., Henig, 2003; Parker, 2005; Prudencio, 2005; Cauchi, 2004; LaRuffa, 2004; Weeks, 2004; Wilson, 2003; Gunderson and Woodward, 2003; Abrams, 2004; Frankel, 2000; Stone, 2003; Harvey, 2005; Rivlin, 2005). Studying electric utilities in particular seems interesting because they have been described as having a strong organisational culture that is more conservative than in other industries and may stifle innovation (Hirsh, 1989).

The paper develops an organisational culture-based model that aims to explain how parent firm organisational culture affects the survival of a CVC fund. We utilise empirical data gathered from $\mathrm{CVC}$ and $\mathrm{VC}$ interviews. The model consists of the 
following components, each of which will be discussed in detail in Sections 5, 6, 7, and 8, respectively:

1 parent firm organisational culture

2 organisational decision-making practices

3 managing and measuring success

4 CVC fund survival.

Propositions are developed that can be tested in future research.

\section{Literature review}

Several authors have looked at CVC as one form for organising innovation within large incumbent firms. Starting with the wider theme of innovation in incumbent firms, we review existing CVC literature with regard to factors that may explain success or failure, and finally review some of the literature on organisational culture with particular regard to innovation.

\subsection{Innovation and incumbent firms}

Levinthal (1997) studied the ability of existing organisations to respond to changing environments and concluded that incumbents in general may have difficulties in adapting to changing environments because the changes negate the value of some of the organisation's existing assets. According to Henderson and Clark (1990) incumbent firms often fail to recognise destruction brought about by 'architectural innovations' that change the architecture of the product without changing its components. Sharma (1999) notes that it is not that incumbents lack creativity and ability to invent new things, but it is "the inertia of past actions, the stifling effects of bureaucracy, and the inflexibility of collective mind-sets that inhabit large firms".

Liabilities of bureaucracy, inertia that accompanies organisational size and aging have contributed to a common perception that start-ups are more innovative than established large firms (Chandy and Tellis, 2000). In addition, radical changes in the business environment can render the skills of the incumbent firms obsolete (Tushman and Anderson, 1986). According to Day and Schoemaker (2000) there are four common pitfalls for incumbents in dealing with emerging technology: delayed participation, sticking with the familiar, reluctance to fully commit and lack of persistence. They emphasise the use of 'early indicators' in order to spot emerging technologies, and encourage firms to look past disappointing results and limited functionality. Similarly, Ahuja and Lampert (2001) identify three traps that inhibit breakthrough inventions in established firms: favouring the familiar (familiarity trap), favouring the mature (maturity trap) and favouring search for solutions near to existing solutions (propinquity trap).

Christensen and Bower (1996) studied the disk driver industry and showed that established firms "led the industry in developing technologies of every sort whenever the technologies addressed existing customers' needs", but at the same time, "projects targeted at technologies for which no customers yet exist languish for lack of impetus and resources". Christensen (1997) introduced a model of disruptive innovation which 
attempts to explain why current industry leaders do well with sustaining innovations but not with disruptive innovations. Disruptive innovations redefine the development trajectory by introducing less advanced products that have other merits such as simplicity or lower costs, targeting new or less-demanding customers. The disruptive innovation gains foothold in the marketplace and starts a cycle of innovation improvement.

Chesbrough (2001), based on a meta-analysis of 16 empirical studies on the impact of technological change upon incumbent firms, proposed a framework consisting of three dimensions that synthesise the findings of the literature: challenge of managing technical complexity, importance of external linkages and the institutional environment. In Chesbrough's (2003) concept of 'open innovation', he states that "in a world of widely distributed knowledge, a company must access external technologies for use in its business and allow its technologies to be accessed by other firms' businesses" [cf., also Chesbrough and Teece (1996)]. One way of institutionalising this link between the company and its external innovation environment is to implement a CVC fund.

\subsection{Corporate venture capital (CVC)}

CVC is one specific form of corporate venturing (von Hippel, 1977; Burgelman, 1985; Block and MacMillan, 1993) or corporate entrepreneurship (Stopford and Baden-Fuller, 1994; Ahuja and Lampert, 2001; Dess et al., 2003) that involves investment intermediation by a dedicated fund (Miles and Covin, 2002). CVC can be described as equity investment into entrepreneurial ventures by established, non-financial corporations. The investment into start-up companies by incumbents "serves as a bridge that connects incumbents to start-ups that are exploring diverse and often competing new technologies that could evolve into technological discontinuities" (Maula et al., 2003).

Most firms create CVC funds with a dual mission in mind, as their goal is to reach both financial (Block and MacMillan, 1993; Chesbrough, 2002; Siegel et al., 1988) and strategic objectives (Rind, 1981; Siegel et al., 1988; Sykes, 1990; Block and MacMillan, 1993; Maula, 2001; Chesbrough, 2000, 2002). The financial objective is to reach rates of return similar to independent $\mathrm{VC}$ funds. However, for many firms gaining strategic benefits is more important (Block and MacMillan, 1993; Rind, 1981; Sykes, 1986). Examples of strategic benefits are identifying future products or technologies, understanding management strengths or weaknesses in acquisitions, designing products faster and at lower cost, gaining a window on technology and offering a way of studying new markets (Rind, 1981). Dushnitsky and Lenox (2005) argue that corporations can learn from CVC investments in entrepreneurial ventures in three ways: First, prior to committing capital, the parent firm can learn through the due-diligence process. Second, an investor may learn about new technologies post investment by maintaining board seats as well as utilising dedicated liaisons. Thirdly, even a failing venture may constitute a learning experience to the extent that it points to remaining technological challenges or market unattractiveness. Maula et al. (2003) argue that incumbents' CVC investments should be used to complement their internal R\&D spending that enhances organisational learning and keeps incumbents' knowledge current. If properly implemented, CVC allows incumbents to develop deep relationships with multiple start-ups, making it possible for them to observe their technological skills and understand their goals, resources and business models. 


\subsection{CVC success factors and challenges}

The financial outcome of CVC funds has been found to vary greatly (Sykes, 1986; Siegel et al., 1988; Gompers and Lerner, 1998; Chesbrough, 2000). On the positive end, Gompers (2002) showed that CVC investments have been at least as successful as independent VC investments in financial terms and the probability of success is substantially higher for funds operating in industries related to the parent company business. According to Siegel et al. (1988), CVC funds that enjoyed greater autonomy in investment decision-making and longer-term financial commitment to the venturing activity reached higher financial return on investment and at least as good strategic benefits as the funds with less autonomy and corporate commitment. Gompers and Lerner (1999) reported similar findings on the importance of a high degree of autonomy. They concluded that greater autonomy combined with long-term commitment prevents the current corporate management from viewing the CVC fund as the pet project of the predecessors. More room to manoeuvre in investment decision-making may also enable the fund to pursue alternative business models in its portfolio, which is one of the advantages of independent VCs over CVCs (Chesbrough, 2000).

On the downside, several studies have reported high failure rates of CVC funds. Challenges faced by the funds may be one reason for the cyclical nature of CVC activities. In general, CVC funds have been found to be more volatile than independent VC funds (Gompers and Lerner, 1998). According to Chesbrough (2000) "the general pattern is a cycle that starts with enthusiasm, continues into implementation, then encounters significant difficulties, and ends with eventual termination of the initiative". Sykes and Dunham (1995) argued that the root of the CVC management problem in corporations is a preconceived mental model about how new ventures should be managed and how performance should be measured. Examples of challenges are problems with venture manager incentives (Block and Ornati, 1987; Chesbrough, 2000), internal politics (Sykes, 1986), or inadequate financial commitment (Siegel et al., 1988). Again, a lack of autonomy might be the root for several of the listed challenges (Siegel et al., 1988).

Comparing corporate and independent venture capitalists, Maula (2001) found that ventures backed by CVCs fared better in initial public offerings than those backed by independent VCs. Gompers and Lerner (1998) have reported that ventures backed by corporate VCs were as successful as those backed by independent VCs when the lines of business of the venture and the investing corporation were similar. This indicates that some firms have been able to use their complementary capabilities to advance the ventures in the CVC fund portfolio (Gompers and Lerner, 1998) and thus gain a competitive edge over independent VCs.

\subsection{Organisational culture and innovation}

Many of the obstacles faced by the CVC funds discussed in the previous paragraph have their source in the interaction between the parent firm and the CVC fund. Thus, the findings of previous research on $\mathrm{CVC}$ indicate that studying the organisational culture of the parent firm, that is defined as being "based upon internally oriented beliefs regarding how to manage, and externally oriented beliefs regarding how to compete" (Davis, 1984), could be helpful in understanding, and possibly even pre-determining, the performance of a CVC activity. In his seminal work, Schein (1985) described organisational culture as the historic result of human actions and decisions, consisting of artefacts, values and 
basic assumptions. According to Schein, organisations typically share basic assumptions on five dimensions: relation between the organisation and its environment; nature of reality and truth; nature of human beings; nature of human activities; and nature of human interactions. Several authors have discussed the relationship between organisational culture and innovation or corporate entrepreneurship. For example, von Rosenstiel (1999) recommends to promote risk-taking, employee initiative, a positive attitude towards innovation and cooperation as cultural aspects of enhancing corporate entrepreneurship. Similar dimensions have been identified by Jaritz (1999). With particular regard to innovation for sustainability, which may be relevant in the context of CVC in the energy sector, Seidl (1993) has taken Schein's five basic assumptions as a starting point to define for each of them an economic, environmental and social dimension, leading to a rather comprehensive survey instrument addressing 45 aspects of organisational culture. Pichel (2003), in her analysis of corporate ecopreneurship, identified four key dimensions of organisational culture, namely the relevance of environmental aspects among the current corporate priorities; the role of the corporate environmental manager as a promoter for innovation; appreciation of individual performance; and openness to change.

Our short review of literature related to organisational culture and innovation highlights that while there is widespread agreement on the importance of cultural factors for explaining organisational behaviour and performance, the wider concept of organisational culture needs to be carefully operationalised in order to be useful in any given context. None of the previous research has had a specific focus on the relation between organisational culture and CVC. Therefore, we will use the broad definition by Davis (1984) rather than apply any of the specific operationalisations discussed above.

It is worth noting that there is an industry-specific aspect of organisational culture. Gordon (1991) presented a model on industry determinants of organisational culture that was described as follows:

\begin{abstract}
"Organizations are founded on industry-based assumptions about customers, competitors, and society, which form the basis of the company culture. From these assumptions, certain values develop concerning 'the right thing to do', and consistent with these values, management develops strategies, structures, and processes necessary for a company to develop its business."
\end{abstract}

Thus certain cultural characteristics will be widespread among organisations in the same industry, and these are most likely different from characteristics found in other industries. This is consistent with the findings of Chatman and Jehn (1994) who investigated similarities in the culture of firms in the same industry. They found that stable organisational culture dimensions existed and varied more across industries than within groups of firms in a particular industry. Because of this industry-specific aspect to organisational culture, the potential for change may often be limited to actions that are neutral to, or directionally consistent with, industry demands.

\title{
3 Methodology and research setting
}

The study employed a grounded theory approach and used CVC and VC interviews as the empirical data source. Interviewees were granted anonymity, therefore individual names of respondents are not disclosed. Our interview partners were principals, managing 
directors or senior investment managers of the fund, with one interviewee for each of the funds listed in Table 1. Where quotes from the interviews are used in this paper, we use the labels $[\mathrm{CVC}]$ and $[\mathrm{VC}]$ to indicate the type of respondent. All-together 27 interviews were carried out among independent and corporate VCs both in Europe and in North America during 2003-2005. The funds were identified through energy sector VC conferences such as European Energy Venture Fair ${ }^{2}$ and Cleantech Venture Forum ${ }^{3}$, and by crosschecking with the Venture Economics database ${ }^{4}$ and with interview partners from our sample. We achieved almost full coverage of the European VC and CVC funds that were actively investing in clean energy technology ventures in 2003-2004. In spring 2005 additional interviews were carried out among North American VCs investing in the same sector in order to lessen possible geographical bias.

Table 1 List of CVC and VC interviews

\begin{tabular}{|c|c|c|c|c|}
\hline Name of the fund & Type of fund & $\begin{array}{l}\text { Fund } \\
\text { location }\end{array}$ & Interview date & Interview type \\
\hline $\begin{array}{l}\text { Norsk Hydro } \\
\text { Technology Ventures }\end{array}$ & Corporate VC & Norway & 6.112003 & Face-to-face (taped) \\
\hline RWE Dynamics & Corporate VC & Germany & 17.22004 & Face-to-face (taped) \\
\hline MVV/Accera & Corporate VC & Germany & 18.22004 & Face-to-face (taped) \\
\hline Eon Venture Partners & Corporate VC & Germany & 19.22004 & Face-to-face (taped) \\
\hline $\begin{array}{l}\text { Vattenfall Europe } \\
\text { Venture }\end{array}$ & Corporate VC & Germany & 5.22004 & Face-to-face (taped) \\
\hline Suez NovInvest & Corporate VC & France & 24.32004 & Face-to-face (taped) \\
\hline $\begin{array}{l}\text { Edf Business } \\
\text { Innovation }\end{array}$ & Corporate VC & France & 25.32004 & Face-to-face (taped) \\
\hline $\begin{array}{l}\text { EdF Capital } \\
\text { Investissement }\end{array}$ & Corporate VC & France & 24.32004 & Face-to-face (taped) \\
\hline $\begin{array}{l}\text { Schneider Electric } \\
\text { Ventures }\end{array}$ & Corporate VC & France & 23.32004 & Face-to-face (taped) \\
\hline $\begin{array}{l}\text { BASF Venture Capital } \\
\text { GmbH }\end{array}$ & Corporate VC & Germany & 18.22004 & Face-to-face (taped) \\
\hline Easenergy & Corporate VC & USA & 17.22005 & Face-to-face (notes) \\
\hline Nth Power & Independent VC & USA & 9.102003 & Face-to-face (taped) \\
\hline SAM Group & Independent VC & Switzerland & 20.82003 & Face-to-face (taped) \\
\hline MSBI Capital & Independent $\mathrm{VC}$ & Canada & 20.102003 & Face-to-face (taped) \\
\hline Innofinance & Independent $\mathrm{VC}$ & Finland & 21.112003 & Face-to-face (taped) \\
\hline Glastad Invest & Independent $\mathrm{VC}$ & Norway & 5.112003 & Face-to-face (taped) \\
\hline PEM-fund & Independent $\mathrm{VC}$ & Finland & 7.112003 & Face-to-face (taped) \\
\hline Proventia Group & Independent VC & Finland & 20.102003 & Face-to-face (taped) \\
\hline Capman & Independent VC & Denmark & 14.112003 & Face-to-face (taped) \\
\hline Apax & Independent VC & Germany & 11.32004 & Face-to-face (taped) \\
\hline Nordstjernan Ventures & Independent VC & Sweden & 29.102003 & Face-to-face (taped) \\
\hline
\end{tabular}


Table 1 List of CVC and VC interviews (continued)

\begin{tabular}{|c|c|c|c|c|}
\hline Name of the fund & Type of fund & $\begin{array}{l}\text { Fund } \\
\text { location }\end{array}$ & Interview date & Interview type \\
\hline Draper Fisher Jurvetson & Independent VC & USA & 1.22005 & Face-to-face (taped) \\
\hline Rustic Canyon Partners & Independent $\mathrm{VC}$ & USA & 26.12005 & Face-to-face (taped) \\
\hline Good Energies Inc & Independent VC & USA & 26.12005 & Face-to-face (taped) \\
\hline $\begin{array}{l}\text { Pacific Corporate } \\
\text { Group }\end{array}$ & Independent VC & USA & 29.32005 & Face-to-face (taped) \\
\hline $\begin{array}{l}\text { California Clean } \\
\text { Energy Fund }\end{array}$ & Independent $\mathrm{VC}$ & USA & 21.32005 & Face-to-face (taped) \\
\hline Chrysalix & Independent $\mathrm{VC}$ & Canada & 24.12005 & Phone interview (notes) \\
\hline
\end{tabular}

All of the interviewed VC funds had made at least one investment into clean energy technologies. Most of the interviewed funds publicly promoted clean energy as one of the fund's focus areas. Our focus on the clean energy technology sector was motivated by three factors. First, the energy industry, which is of huge economic importance, is currently under a pressure to change. Second, the energy sector is attracting a growing amount of attention from VCs (Parker, 2005). Third, since European CVC funds have been active investors in the clean energy market it was expected that interesting and rich research data would be available by focusing on clean energy. In this study clean energy is defined as providing energy technologies and services that reduce environmental impacts, are socially acceptable and can be economically competitive (Moore and Wüstenhagen, 2004). Clean energy technologies and services can be divided into four main clusters: renewable energy, distributed energy systems, natural gas and demand-side energy efficiency (Pfeuti et al., 2002).

\section{Conceptual model}

In order to gain a better understanding of the factors that determine the survival of a CVC fund, we took a perspective that concentrated on the organisational culture of the parent firm. We argue that selecting organisational culture as the viewpoint of the analysis will provide fresh new perspectives on the survival challenges that CVC funds face. Without explicitly referring to the concept of organisational culture, some of the previous findings or CVC research discussed above hint to cultural aspects of the parent firm, such as venture manager incentives, internal politics or low level of fund autonomy. Another aspect that makes our perspective promising is the link between organisational culture of the parent firm and the surrounding industry context (Gordon, 1991). None of the previous CVC research has had an empirical focus on the energy sector. Instead, CVC researchers tended to rely on empirics from information technology, telecommunications or pharma industries. Our study is based on empirical data from the energy sector where the industry context differs from these sectors in many respects such as in market concentration, regulation and patenting activity. Analysing energy sector CVC fund investments into clean energy ventures may therefore bring out new perspectives that have gone unnoticed in previous research. 
The dependent variable of our research is survival of the CVC fund. While previous literature has discussed various indicators for measuring the achievement of financial and strategic objectives of a fund, we argue that in order to achieve financial and strategic objectives, survival of a CVC fund is a necessary prerequisite. As we will find in our sample, even this basic prerequisite is not fulfilled in many cases, rendering a more detailed discussion of financial or strategic performance obsolete.

Figure 1 Conceptual model to explain CVC fund survival

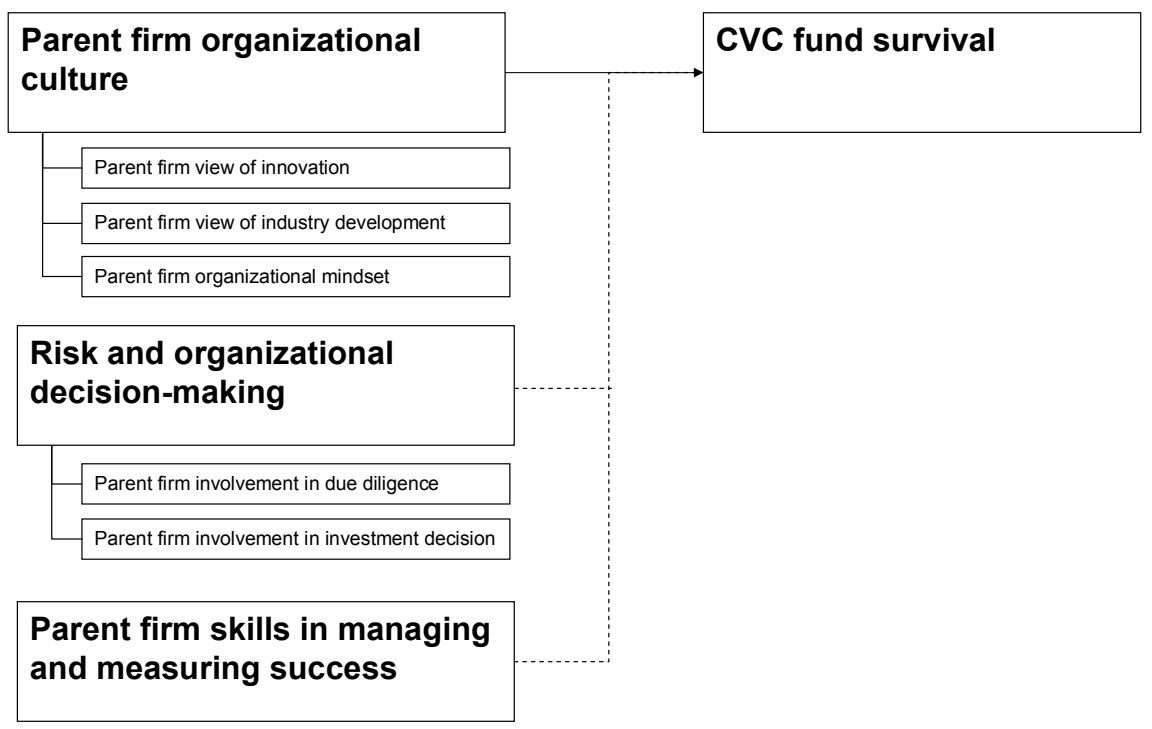

The explanatory model shown in Figure 1 emerged as a result of the data analysis of $\mathrm{CVC}$ and $\mathrm{VC}$ interviews, and previous research findings on organisational culture, industry context and decision-making behaviour. The model is based on the argument that the parent firm organisational culture affects CVC fund survival. The effect of the organisational culture is moderated by risk taking practices in the parent firm decision-making process and the parent firm skills in managing and measuring fund success. Therefore, depending on the strength and nature of the two moderating factors, the parent firm organisational culture may have more or less effect on the CVC fund survival. The following sections discuss the elements of the model in more detail.

\section{Parent firm organisational culture}

CVC funds operate as separate entities within the parent company, some more autonomous than others. CVC managers interact with the parent company in investment decision-making, due diligence and other services such as legal support. When we 
analysed the empirical data from our interviews, a large amount of the CVC fund challenges were linked to interaction with the parent company. When these challenges were analysed further, three main factors related to parent firm organisational culture were identified: parent firm view on innovation, parent firm view of industry development and parent firm organisational mindset. These three factors will be discussed in detail below.

\subsection{Parent firm view of innovation}

From the CVC and VC interviews two issues were identified regarding innovation in the energy sector. First, many electric utilities did not perceive innovation as a key competitive advantage, which in turn made the life of a CVC fund difficult as it tried to identify new innovative business models promoted by start-up firms. Second, even in cases where the parent firm had realised that scouting for new innovative business approaches was important, the parent company saw no urgency to act. The lack of urgency was due to the fact that parent companies were used to reacting to external regulatory pressures, not to business threats imposed by new external ventures. In other words, the CVC activity was not perceived as a crucial activity, but rather as a convenient approach to keep track of the latest market developments.

The term innovation has become a buzzword in many industrial sectors such as biotech, pharmaceuticals and ICT. The energy sector seems to have headed to the opposite direction in innovation when measured in terms of R\&D spending both in the public and private sector. Kammen and Nemet (2005) studied the US energy industry and found that both the federal government and the private industry had cut investments in energy R\&D "at a time when geopolitics, environmental concerns and economic competitiveness call instead for a major expansion in US capacity to innovate in this sector". Their analysis shows that investments into energy R\&D by US companies fell by $50 \%$ between 1991 and 2003. When energy sector R\&D spending is compared with other sectors, such as biotech, the picture is even bleaker. Total private sector energy R\&D is less than the R\&D budgets of individual biotech companies such as Amgen or Genentech (Kammen and Nemet, 2005). An interviewed VC commented on the electric utilities as follows:

[VC]: The way that the power industry has changed in the last three years has been one of reverting back to the kind of core business of serving customers, generating electrons and managing risks and things like that. Not really about innovation and not about innovating service. So, I think most of them have done away with innovation culture.

However, previous research has shown that in order for the CVC activity to be successful, the parent firm must make venturing a mainstream function of the business (Sykes and Block, 1989) or create an atmosphere and structure that supports the innovative activity (Quinn, 1985). In other words, the parent firm organisational culture must provide a supportive structure for innovation, which may consist, for example, of R\&D or other corporate venturing activities within the parent firm (Dushnitsky and Lenox, 2005). Creating a culture that nurtures innovation may take a long time to develop. According to March (1988) preferences tend to adapt in response to experience. Therefore, firms that have not developed competencies for innovation and R\&D 
operations, also tend to lack a taste for these activities, which in turn shows in the level of organisational support a CVC fund enjoys.

Currently the large electric utilities have a strong hold of their customers, but not on energy technologies. They are in the business of generating and supplying electricity, but they are not in charge of bringing new technological innovations to the energy sector. For many electric utilities, competitive advantage through innovation is not a familiar concept. Kammen and Margolis (1999) have argued that cutbacks in energy R\&D during the past decades have reduced the capacity of the energy sector to innovate. In the words of one interviewed CVC fund manager:

[CVC]: The message is that it is really difficult to make a CVC unit exist [in a large electric utility] when you are not convinced that innovation will be the key in competition. In the corporate level they don't think that innovation will be the key in winning the competition. They think it is the price or classical services.

The independent VCs that had observed the energy company CVC fund activities, were more optimistic about the chances of success of CVC funds backed by large energy technology companies than of the funds backed by electric utilities.

[VC]: [Energy technology companies] are the ones that ultimately are much more focused on innovation [than electric utilities] because they know how to absorb it and turn it into a value proposition. There's very little that an electricity company can innovate on, because again ultimately I think that they are just in the core business of selling you know electrons. And there are no big changes that have happened (...) since the beginning of the last century that have really changed the way that wholesale power has been delivered to customers.

Proposition 1 A parent firm, whose organisational culture does not view innovation as a key component in gaining competitive advantage, negatively affects the survival of a CVC fund.

\subsection{Parent firm view of industry development}

From the CVC fund interviews, a theme was identified regarding parent firm view of industry development. The theme is concerned with the parent firm not recognising that the surrounding business environment is undergoing a change and acknowledging that some of the new entrants could potentially threaten the firm's market position.

According to Bettis and Hitt (1995) the 21st century faces new aspects of competition and strategy due to rapid technological change including the blurring of traditional industry boundaries as substitute products are developed in other industries. This phenomenon is currently starting to take hold in the energy sector. For example, several of the independent VCs that have focused on the clean energy market have large non-energy corporations as investors. One example is the Canadian fuel cell VC fund Chrysalix, whose investors include companies like Ballard, BASF, BOC, Boeing, and Mitsubishi.

An interviewed CVC manager commented on the views of his parent company managers on the change that was taking place in the energy sector: 
[CVC]: This industry is moving slowly, the driver is not technology but market power. So we are not really in the battle, even if [the new market entrants] claim that we are in a battle. In the mind of a manager, we are not in a battle. So we are anticipating here and it is not easy to anticipate in big companies.

Regulatory authorities rather than market forces were seen as driving innovation in the energy sector, and where regulatory pressure was low, there seemed to be little incentive to innovate.

[CVC]: I think the extent to which the established corporations like [our company] are ready to accept innovation and invest in new business models largely depends on the regulatory framework. Because it is relatively stable they do not have any urgency to change their business model. Just do nothing and do nothing new, is the best strategy. I'm definitely convinced that this is the best strategy.

Many of the interviewed CVC fund managers indicated that the parent company views on the changes in the surrounding industry context and the introduction of new business models were conflicting with the views of the CVC fund, especially when it came to assessing the speed of change taking place.

According to Aldrich and Fiol (1994), established industries may withhold recognition or acceptance of the new industry when they feel threatened. Sometimes they are even able to change the terms on which resources are available to emerging industries. This kind of blocking behaviour was not foreign to the CVC managers, who had involved parent firm managers in the CVC fund investment decision-making:

$[\mathrm{CVC}]$ : Then we have had deals that have been very convincing. And [corporate headquarters] say, "People are great, as a technology it seems to be very, very interesting". Then came: "if these guys become a success, they will cannibalize our business. We cannot invest in a company that is cannibalizing our own business".

Abernathy and Utterback (1978) and Utterback (1994) have investigated different phases of product and process innovation in an industry. They pointed out a general pattern of the emergence of new industries, where innovation initially takes place at a high rate and many new players enter the market, followed by a phase of consolidation. Making sense of the new developments in an emerging industry may be challenging. According to Sanders and Boivie (2004), during the emergence of new industries, investors and analysts lack a codified body of knowledge and industry-specific experience. Therefore, identifying the winning business models among the various unproven but interesting models explored by competing start-up firms is difficult even for an energy-company backed CVC fund manager. The CVC fund managers were at times in a position, where they saw potential threats to the status quo of the parent company, but no serious counter-act on behalf of the parent company itself:

[CVC]: I'd say it is not very easy to compete against [our parent company]. So perhaps we don't see the sign [that we need to act], we see a lot of start-ups working on these systems to measure the consumption, to evaluate the right services to cut on consumption. But we don't see a big movement of large energy companies heading to catch the value of these start-ups.

Proposition 2 A parent firm, whose organisational culture supports a perception of industry stability and belittles the speed of technological change, negatively affects the survival of a CVC fund. 


\subsection{Parent firm organisational mindset}

Two themes related to parent firm organisational mindset emerged from the CVC and VC interviews. The first theme was differences in the organisational mindset of the fund and the parent company. Second, a lack of entrepreneurial thinking and mindset within the parent firm caused conflicts in the CVC fund - parent firm interaction.

Levinthal and March (1993) argued that organisations find and construct their private comprehensible worlds. The parent firm worldview or organisational mindset may differ strongly from the one present in the $\mathrm{CVC}$ fund. The organisational culture mismatch may lead to a clash of management cultures if the parent firm does not provide adequate autonomy for the venturing activity to establish its own management processes. An interviewed CVC fund manager commented about a clash he had experienced with the parent company as follows:

[CVC]: [Our company] of course tried to duplicate their controlling system here at [our CVC fund]. And I said, hey, I'm not willing to accept this. Otherwise you are calculating every project to death. You are not able to [apply the corporate] mindset [to a CVC fund]. We have a different mindset and culture.

Changing the prevailing mindset means adopting a different worldview. Electric utilities have in many countries until recently been part of a government owned and regulated entity. For these firms, switching to entrepreneurial mode of operation and thinking can be difficult. An interviewed CVC fund manager was frustrated and commented the lack of entrepreneurial spirit in his parent company:

[CVC]: You always have to ask why people are working with a big conglomerate or a big energy company and not working as an entrepreneur. They have a different spirit. And I asked a board member, (...) and he said: "Look at these people. They are not entrepreneurs. So you are trying to do something that is impossible, to move these people to your side".

Another interviewed CVC fund manager described his parent company's research centre activities as follows:

[CVC]: It is always a question of people. And if you have a research centre with 100 people or 200 people, they can gather all the information available in the world about technologies and trends and so on. But they are not thinking in terms of business, they are just thinking in terms of a department that delivers information.

Foster (1986) has shown that the reason incumbent firms fail in the face of technical change is not due to the character of the technology but the cognitive errors the managers made in understanding the challenge of the emerging industry context. One interviewed independent $\mathrm{VC}$ fund manager, who had been following the CVC activities of energy companies, commented on the willingness of electric utilities to engage in business activities with small firms as follows:

[VC]: The other characteristic of this industry might be that the utilities have a tendency to really only want to work with more mature companies and not with companies that they are concerned would disappear. Whereas you see in companies like Cisco or maybe even in the Biotech area partnerships between small lab companies and these big pharmaceutical companies. And, you know, lab companies don't make the required discovery or something like that. They disappear or go away but this is probably their whole plan to work with this 
diversified portfolio of small companies. Utilities don't seem to approach it that way. So you have to pass a certain level of maturity before the utilities really want to do business with you.

In a similar fashion Henderson (1996) found that radical innovation could displace incumbent firms for organisational reasons due to cognitive limits and inertia, in addition to the more rational reasons such as unwillingness to render existing assets obsolete. One example of cognitive limits is the inability to adapt to a new way of serving the customers. An interviewed VC fund manager commented on the electric utilities and the way they conducted their business as follows:

[VC]: So far they've always looked like "we are the utility and you are the subscribers". And not like" you are the customer, how can I serve you and make a business" [...] And that is an attitude that, you know, "it has worked so let's not change it".

Proposition 3 Lack of entrepreneurial spirit within the parent firm negatively affects CVC fund survival.

\section{Risk and organisational decision-making}

In the CVC fund interviews two themes emerged regarding organisational decision-making under risk, mainly concerned with due diligence and investment decisions. The first theme, gaining an outside view both in technical and market assessment through the parent company involvement in the preparation of CVC fund investment decisions, and thus balancing possible overconfidence of CVC fund managers, has a potentially positive effect on CVC fund survival. The second theme, involving parent firm managers with no venturing experience in the decision-making, has a negative effect on fund survival.

We argue that parent firm risk-taking practices in the organisational decision making process moderate the effects of parent firm organisational culture on the survival of the CVC fund, as shown in Figure 1. The decision-making process regarding the fund investments often involves managers both from the parent firm and the CVC fund, making the decision-making behaviour and the biases each party brings to the table critical for the quality of decisions on venture investments and divestments, and the fund's investment policy.

The basic assumptions and values that are part of organisational culture also affect decision-making in organisations. Kahneman and Lovallo (1993) studied cognitive perspectives of decision-making and argued that decision makers in organisations are prone to two types of biases. First, their forecasts of future performances are often anchored on plans and scenarios of success rather than on past results, and are therefore overly optimistic. Second, their evaluation of single risky prospects neglects the possibilities of pooling risks and is therefore overly timid. Kahneman and Lovallo (1993) introduced a concept of and inside view and an outside view. The inside view is generated by focusing on the case at hand, by considering the plan and the obstacles to its completion, by constructing scenarios of future progress, and by extrapolating current trends. The outside view is a conservative approach that relies on statistics of similar cases to the present one. 
One example of the outside view upside effect is the help provided by a parent firm's technical experts in the due diligence process. The interviewed CVC fund managers tended to appreciate the technical expertise that they received from within the parent company.

[CVC]: If you are investing in start-up companies, [the knowledge needed] is definitely more on the technical side, definitely. The evaluation of the technology is really the core and very essential for calculating the risk and reward scheme.

Parent firm managers can offer the 'outside view' to CVC managers in order to help balance the overly optimistic scenarios and thus avoid hype over a certain technological solution.

[CVC]: For our investments, we have invested in very early stage companies. It was really technical due diligence and we were working closely together with [our parent company] engineering. And they do have four or five hundred specialists. Every specialist has really a specific area that he is concentrating on so you really get the best of technical experiences.

Involvement of parent company personnel may also shield the CVC fund managers from overconfidence. Managers may view risk as a challenge to be overcome and believe that risk can be modified by 'managerial wisdom and skill' (Kahneman et al., 1991; Donaldson and Lorsch, 1983). Zacharakis and Shepherd (2001) showed that VCs are overconfident in their decision-making and the same result can be assumed to apply also to CVC fund managers.

$[\mathrm{CVC}]$ : In the beginning we were very broad. Everything was energy but we were able to invest in batteries for example which was really not core of the energy business. But we were able to do almost everything. And it was really essential to do so. But as soon as we got into discussions with the operating units, and we had to get into contact, whenever we make a project or an investment of course we have to involve them and to get some technical feedback.

One example of the outside view downside effect is the involvement of parent firm managers with no venturing experience in the investment decision-making. Parent firm manager involvement in the venture investment decision-making process may lead to overly timid decisions, demonstrating loss aversion as losses and disadvantages are weighted more than gains and advantages, favouring inaction over action and the status quo over any alternatives (Kahneman and Lovallo, 1993).

[CVC]: I had very deep discussion with all the board members, and also the ones that have been on my side. And I discovered one phenomenon. They feel definitely uncomfortable in making the decision if they were not able to understand the business. And you are not doing them a favour by giving them a proposal. The better way is to say, "Give me the money and let other people to decide for this money". So they can always say: 'It was somebody else's decision'.

The loss aversion problem becomes especially severe, when the CVC fund has to involve parent firm managers in the investment decision-making who have not enough market or technical knowledge to judge the investments accordingly. This involvement may lead to excessive loss aversion and inhibit the CVC fund from necessary risk-taking. Kahneman and Lovallo (1993) proposed that one way to avoid excessive risk aversion is to analyse 
if the organisational context in which the decisions are made is more likely to enhance or inhibit risk aversion. As the quotes below demonstrate, involvement of the parent firm inexperienced managers clearly enhanced the risk aversion in investment decision-making.

[CVC]: The problem was the corporate headquarter (HQ). The people who were deciding about the investments, they were corporate people from corporate HQ, they didn't have any knowledge of the technical things and the market things. So they were very insecure.

Fighting against loss aversion may require CVC managers spending time on internal lobbying work, instead of focusing on the operation of the fund.

[CVC]: So you have to convince people about the VC idea, who have not ever thought about VC. And maybe you get $50 \%$ of them if you are really convincing. So it was pretty much fighting against the organization.

Proposition 4A Parent company involvement in technical and market due diligence positively affects the survival of the CVC fund.

Proposition 4B Parent company involvement in investment decision-making negatively affects the survival of the CVC fund.

\section{Measuring and managing success}

An important theme that emerged from the CVC interviews, parent firm skills in measuring and managing success, is argued to moderate the effects parent firm organisational culture has on the survival of the CVC fund, as shown in Figure 1. We use the term measuring success to describe the methods parent firms use to quantify the strategic and financial benefits for the firm. The term managing success is used to analyze the way firms reward the fund managers, the extent to which out-of-the-box thinking is encouraged and the level of trust and patience the parent firm has on the fund managers.

Managing success requires understanding what Levinthal and March (1993) have referred to as the political structure of an organisation. Managers who have been successful in the past are launched into positions of power in the organisation. These individuals tend to carry the recipe for past successes in their mind, which discourages out-of-the-box thinking. As Levinthal and March (1993) argued, "Organizations code outcomes into successes and failures and develop ideas and causes for them". This easily leads to a situation where unconventional thinking within the CVC fund is not supported or rewarded from the parent firm side. Levinthal and March (1993) also noted that since return from any particular innovation or technology is partly a function of the organisation's experience of the new idea, even successful innovations tend to perform poorly at first until the organisation has gathered experience. An interviewed CVC fund manager commented about his parent firms' disability to support innovative approaches the fund was trying to promote as follows:

[CVC]: The problem [with venturing] is that if you are really innovative you get in trouble with the traditional organization... And if [the ventures] are gaining market share, the headquarter or the operating unit is losing market share. And losing market share in the traditional sector or an operating unit is valued more than chances in the new growth area. 
All of the interviewed CVC funds were small compared to the annual turnover of the parent company. This may lead to a situation where only failures get punished but success goes without noticing. As an interviewed CVC fund manager comments:

$[\mathrm{CVC}]$ : So we have only risk and even if you are very, very successful it'll never be so successful that it will be reported in the quarterly report. So we as a supervising team can only lose. So if the money is away the shareholders are asking what happened to our money, is it really necessary to do these kinds of investments. And if you're successful it is 'so what'.

Not having a clear view of how strategic benefits were measured and compensated and what was regarded as a successful execution of strategic objectives was also found as a constraining factor in the CVC fund manager interviews. Since finding the balance between strategic and financial objectives appears to be difficult, the fund managers may try to follow the traditional VC model and concentrate solely on the financial return.

[CVC]: So basically it means we go after profits. If you don't go after the profits, how do you know what you're finding? Is it going to be the market leader in the future? So by definition if you can't spot the best deals and get the best returns, you cannot spot what the market is doing.

Measuring the success of the CVC activity is challenging since the investment committee, consisting often of both parent firm managers and fund managers, needs to be able to quantify the strategic value of a venture investment in addition to the potential of future financial returns. Emerging industry operating procedures, competitive environment, firm size and market dominance strategies may differ from the current industry context, making the strategic value quantification difficult for managers tuned to the current industry context. An attempt to fulfil the strategic goals may require easing on the financial targets:

[CVC]: I'm now concentrating on delivering strategic benefits and maybe I'm suffering on the return side, because I cannot invest so many resources to making financially really attractive deals.

The financial returns from small ventures may appear modest when benchmarked against the existing business units. Parent company managers may also see an investment into a venture as threatening and to contain a negative strategic value for the parent firm, especially if an investment is syndicated including CVCs of competing firms. As an interviewed CVC fund manager comments:

[CVC]: It was odd to have so many other corporate [funds] investing there. It is very hard to argue for this investment from a strategic point of view. If you go to your investment committee they say, "Ok, it is an interesting case and you have these risks and opportunities." But then they also notice that [our main competitor] is inside and then they say, "Hey what is here the competitive advantage. Maybe it is a disadvantage if they invest and we don't". But this is not so convincing. It is always more convincing when you say "We have this exclusive deal and if it is a big hit we have the advantage to acquire the rest of the shares and make a huge business out of it". That is really convincing.

Proposition 5 Parent firms who have not been able to develop appropriate mechanisms to measure both strategic and financial success of the fund negatively affect the survival of the CVC fund. 
Table 2 Status of CVC funds in the energy sector as of January 2006

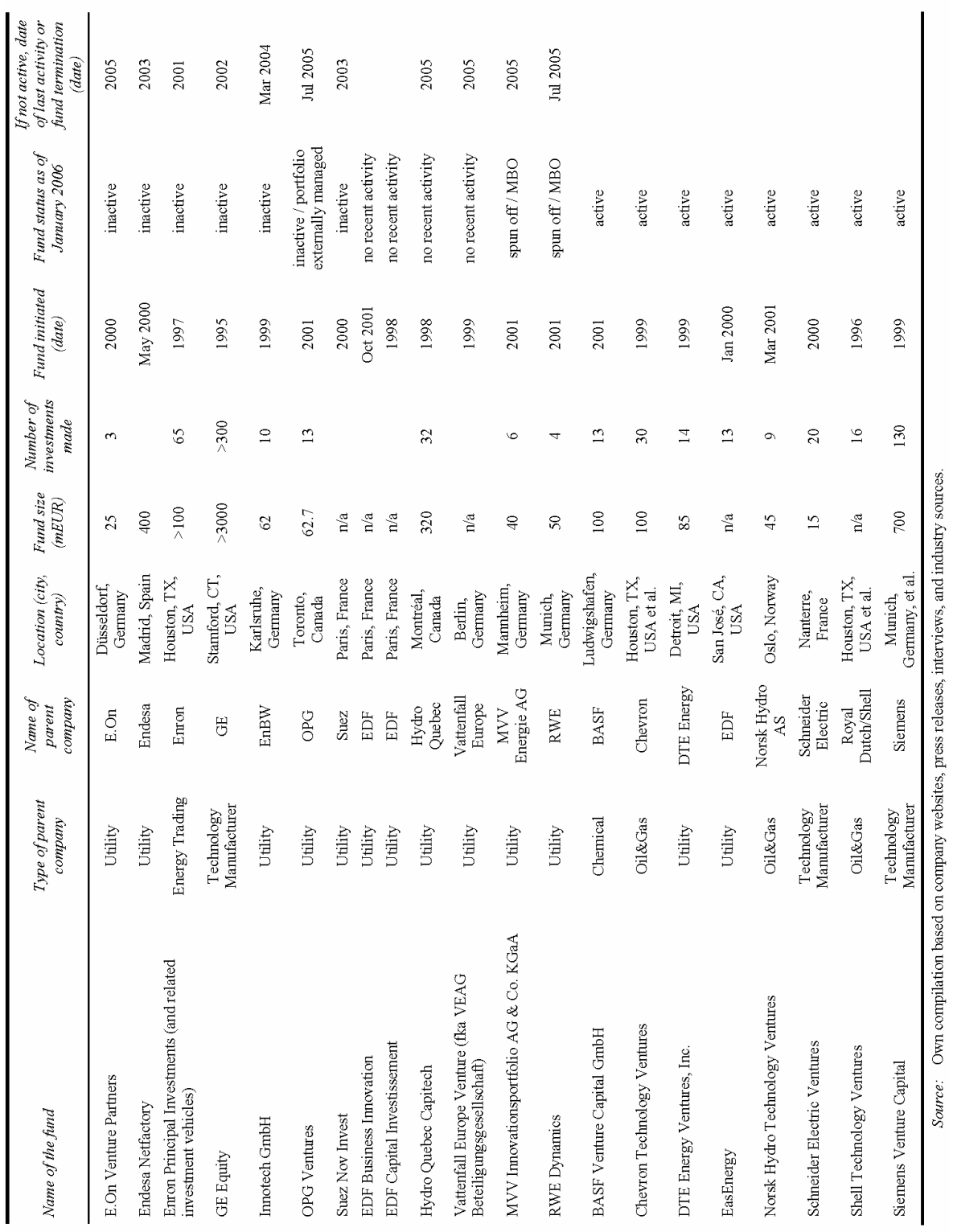




\section{CVC fund survival}

We carried out the majority of our CVC fund interviews between fall 2003 and spring 2004 (Table 2). Looking at the current status of CVC funds in the energy sector in January 2006, it appears that eight of the 11 CVC funds that we interviewed were either spun off, not actively investing or had been closed down altogether, indicating a significant failure rate. As for the specific industry background of the parent company, it is striking that electric utility-backed CVC funds appear to fail most often, whereas the survival rate has been a bit higher common among oil company CVCs and power technology manufacturers. Relating this to the cultural differences, particularly between conservative utilities and the more innovation-driven power technology manufacturers, seems to support our argument about the importance of organisational culture. No clear trend seems to exist among different geographical regions, with North American CVCs failing roughly as often as European funds. Fund size also did not seem to make a major difference, with both failing and surviving funds ranging from a few dozen million Euros to several hundred million Euros. Table 2 summarises the status of CVC funds in the energy sector as of January 2006.

\section{Discussion and conclusions}

Our discussion of organisational culture and CVC fund survival has shed new light on the important issue of how to successfully manage a CVC vehicle. It has demonstrated that incumbent firms face big challenges in renewing their business through CVC activities because of the constraints related to their organisational culture. By disentangling organisational culture into three sub-factors, namely parent firm view of innovation, parent firm view of industry development, and parent firm organisational mindset, and supplementing it with two related factors, namely risk and organisational decision-making and parent firm skills in managing and measuring success, we proposed a model that helps to explain why some CVC funds are more successful than others. Our empirical insights in the energy sector, and particularly among electric utilities operating CVC funds, illustrated the cultural mismatches between CVC units and their parent firms. Therefore, the empirical finding that a majority of energy CVC funds have been closed only a few years after they were launched is well in line with our proposed model. On a more constructive note, we could also determine that some companies are more likely to succeed with CVC than others. This is underlined by the fact that many, but not all of the energy CVC funds that we interviewed have failed. Of those that remain active, there seems to be an over-representation of firms that meet the necessary cultural requirements to interpret innovation as an essential element of their core business, and not as either a temporary management fad or even a threat to the basic assumptions of the organisation. On average, electric utilities, whose organisational culture is built around notions of industry stability and risk aversion, seem to struggle more with CVC than for example energy technology manufacturers, for whom innovation is an essential element of competitive advantage.

The study results bear implications for corporations that are planning to launch corporate venturing activities. The findings suggest that firms should closely analyse the parent firm organisational culture and the industry context where the firm operates. In 
this way the firm could identify the potential shortcomings in its organisational culture such as view of innovation and of industry development, as well as the organisational mindset prior to setting up the fund. A further study on decision-making processes and skills in managing and measuring success could be carried out in the firm to alleviate the negative effects, potentially leading to a better outcome of the corporate venturing activity.

As this paper was concerned with theory building rather than testing existing theory, a number of limitations to the results exist. Our findings are based on empirical qualitative data. The results have not been tested in a quantitative manner. In addition, the theoretical scope is limited to CVC as one specific form of innovation in large incumbent firms. The empirical data of this paper is drawn from venture capital firms and CVC funds in Europe and North America.

The findings and limitations suggest several avenues for future research. First of all, the developed models and propositions should be quantitatively tested and further refined. It would also be interesting to use empirical data from another industry in the quantitative testing of the results of this study. Furthermore, the effect of parent firm organisational culture on the CVC fund survival warrants a further investigation.

\section{Acknowledgements}

The authors would like to thank participants of the DRUID Summer Conference 2006 on 'Knowledge, innovation and competitiveness' in Copenhagen/Denmark, as well as the 2006 GRONEN Conference on 'Sustainability management, innovation and entrepreneurship' in St. Gallen/Switzerland for their suggestions and valuable comments on an earlier draft of the paper. We also appreciate specific feedback received from Tima Bansal, Steffen Hasselwander, Bill Moore and Mike Russo. Finally, we are grateful to the corporate and independent venture capitalists that we interviewed for sharing their valuable time and insight. All remaining errors are the sole responsibility of the authors.

\section{References}

Abernathy, W. and Utterback, J. (1978) 'Patterns of industrial innovation', Technology Review, June/July, pp.40-47.

Abrams, S. (2004) 'Clean energy investments are growing', Pipeline \& Gas Journal, January, p.14.

Ahuja, G. and Lampert, C.M. (2001) 'Entrepreneurship in large corporation: a longitudinal study of how established firms create breakthrough inventions', Strategic Management Journal, Vol. 22, Nos. 6-7, pp.521-543.

Aldrich, H.E. and Fiol, M.C. (1994) 'Fools rush in? The institutional context of industry creation', Academy of Management Review, Vol. 19, No. 4, pp.645-670.

Bettis, R. and Hitt, M.A. (1995) 'The new competitive landscape', Strategic Management Journal, Vol. 16, pp.7-19.

Block, Z. and MacMillan, I. (1993) Corporate Venturing, Harvard Business School Press, Cambridge, MA.

Block, Z. and Ornati, O.A. (1987) 'Compensating corporate venture managers', Journal of Business Venturing, Vol. 2, pp.41-52.

Burgelman, R.A. (1985) 'Managing the new venture division: research findings and implications for strategic management', Strategic Management Journal, Vol. 6, pp.39-54. 
Cauchi, M. (2004) 'Energy investment sees a revival', The Wall Street Journal Europe, 31 March.

Chandy, R. and Tellis, G. (2000) 'The incumbent's curse: incumbency, size and radical product innovations', Journal of Marketing, pp.1-17.

Chatman, J.A. and Jehn, K.A. (1994) 'Assessing the relationship between industry characteristics and organizational culture: how different can you be?', Academy of Management Journal, Vol. 37, No. 3, pp.522-554.

Chesbrough, H. and Teece, D. (1996) 'When is virtual virtous: organizing for innovation', Harvard Business Review, Vol. 74, No. 1, pp.65-74.

Chesbrough, H.W. (2000) 'Designing corporate ventures in the shadow of private venture capital', California Management Review, Vol. 42, No. 3, pp.31-49.

Chesbrough, H. (2001) 'Assembling the elephant: a review of empirical studies on the impact of technical change upon incumbent firms', in Burgelman, R. and Chesbrough, H. (2001): Research on Technological Innovation, Management, and Policy, Vol. 7, pp.1-36, JAI Press.

Chesbrough, H.W. (2002) 'Making sense of corporate venture capital', Harvard Business Review, Vol. 80, No. 3, pp.90-99.

Chesbrough, H.W. (2003) Open Innovation: The New Imperative for Creating and Profiting from Technology, Harvard Business School Publishing, Cambridge, MA.

Christensen, C.M. (1997) The Innovator's Dilemma: When New Technologies Cause Great Firms to Fail, Harvard Business School Publishing, Cambridge, MA.

Christensen, C.M. and Bower, J.L.. (1996) 'Customer power, strategic investment, and the failure of leading firms', Strategic Management Journal, Vol. 17, pp.197-218.

Davis, S.M. (1984) Managing Corporate Culture, Ballinger, Cambridge, MA.

Day, G.S. and Schoemaker, P.J.H. (2000) 'Avoiding the pitfalls of emerging technologies', California Management Review, Vol. 42, No. 2, pp.8-34.

Dess, G.G., Ireland, R.D., Zahra, S.A. Floyd, S.W., Janney, J.J. and Lane, P.J. (2003) 'Emerging issues in corporate entrepreneurship', Journal of Management, Vol. 29, No. 3, pp.351-378.

Donaldson, G. and Lorsch, J. (1983) Decision Making at the Top, Basic Books, New York.

Dushnitsky, G. and Lenox, M.J. (2005) 'When do incumbents learn from entrepreneurial ventures? Corporate venture capital and investing firm innovation rates', Research Policy, Vol. 34, pp.615-639.

Foster, R.N. (1986) Innovation: The Attacker's Advantage, Summit Books, New York.

Frankel, A. (2000) 'New energy in venture capital', Electric Perspectives, November/December, pp.54-62.

Gompers, P. (2002) 'Corporations and the financing of innovation: the corporate venturing experience', Economic Review - Federal Reserve Bank of Atlanta, Vol. 87, No. 4.

Gompers, P. and Lerner, J. (1998) 'The determinants of corporate venture capital success: organisational structure, incentives, and complementarities', NBER working paper \#6725.

Gompers, P. and Lerner, J. (1999) The Venture Capital Cycle, MIT Press, Cambridge, MA.

Gompers, P. and Lerner, J. (2001) 'The venture capital revolution', Journal of Economic Perspectives, Vol. 15, No. 2, pp.145-168.

Gordon, G.G. (1991) 'Industry determinants of organisational culture', Academy of Management Review, Vol. 16, No. 2, pp.396-415.

Gunderson, M. and Woodward, T. (2003) 'Energy fundamentals still strong, but caution rules the day', Venture Capital Journal, February, pp.50-51.

Harvey, F. (2005) 'Time to clean up? The climate is looking healthy for investment in green technology', Financial Times, 22 June.

Henderson, R. (1996) 'Product development capability as a strategic weapon: Canon's experience in the photolithographic industry', in Nishiguchi, T. (Ed.): Managing Product Development, Oxford University Press, New York. 
Henderson, R.M. and Clark, K.B. (1990) 'Architectural innovation: the reconfiguration of existing product technologies and the failure of established firms', Administrative Science Quarterly, Vol. 35, No. 1, pp.9-20.

Henig, P. (2003) 'Cover story: bright idea', Venture Capital Journal, 1 November.

Hirsh, R.F. (1989) Technology and Transformation in the American Electric Utility Industry, Cambridge University Press, Cambridge.

Jaritz, A. (1999) TQM und Mitunternehmertum im Humanressourcenmanagement, Hampp (zugl. Diss. Univ. St. Gallen), München.

Kahneman, D. and Lovallo, D. (1993) 'Timid choices and bold forecasts: a cognitive perspective on risk taking', Management Science, Vol. 39, No. 1, pp.17-31.

Kahneman, D., Knetch, J.L. and Thaler, R.H. (1991) 'Anomalies: the endowment effect, loss aversion, and status quo bias', Journal of Economic Perspectives, Vol. 5, No. 1, pp.193-206.

Kammen, D.M. and Margolis, R.M. (1999) 'Underinvestment: the energy technology and R\&D policy challenge', Science, Vol. 285, No. 5428, pp.690-692.

Kammen, D.M. and Nemet, G. (2005) 'Real numbers. reversing the incredible shrinking energy R\&D budget', Issues in Science and Technology, Fall.

LaRuffa, V. (2004) 'The (re-)emergence of energy technology', AltAssets, 16 June, available at www.altassets.com.

Levinthal, D.A. (1997) 'Adaptation on rugged landscapes', Management Science, Vol. 43, No. 7, pp.934-950.

Levinthal, D.A. and March, J.G. (1993) 'The myopia of learning', Strategic Management Journal, Vol. 14, pp.95-112.

March, J.G. (1988) Decisions and Organizations, Blackwell, Oxford.

Maula, M.V.J. (2001) 'Corporate venture capital and the value-added for technology-based new firms', Doctoral dissertation, Institute of Strategy and International Business, Helsinki University of Technology.

Maula, M.V.J., Keil, T. and Zahra, S.A. (2003) 'Corporate venture capital and recognition of technological discontinuities', Proceedings of the Annual Meeting of the Academy of Management, Seattle, WA, USA.

Miles, M.P. and Covin, J.G. (2002) 'Exploring the practice of corporate venturing: some common forms and their organisational implications', Entrepreneurship Theory and Practice, Vol. 26, No. 1, pp.21-40.

Moore, B. and Wüstenhagen, R. (2004) 'Innovative and sustainable energy technologies: the role of venture capital', Business Strategy and the Environment, Vol. 13, pp.235-245.

Parker, N. (2005) 'Cleantech's players, performance and potential', Environmental Finance, March, available at www.environmental-finance.com.

Pfeuti, R., Flatz, A., Moor, M., Wüstenhagen, R. and Zamboni, M. (2002) Changing Climate in the Energy Sector - A New Wave of Sustainable Investment Opportunities Emerges, 2nd ed., SAM Sustainable Asset Management, Zurich, available at http://www.sam-group.com.

Pichel, K. (2003) 'Innerbetriebliches Ecopreneurship durch Umweltmanagement-systeme? Eine empirische Analyse von Bedingungen umweltbewussten Arbeitsverhaltens', dissertation.de, zugl. Diss. TU Berlin, Berlin.

Prudencio, R. (2005) 'The next disruptive technology', Public Utilities Fortnightly, April.

Quinn, J.B. (1985) 'Managing innovation: controlled chaos', Harvard Business Review, May-June, pp.73-84.

Rind, K. (1981) 'The role of venture capital in corporate development', Strategic Management Journal, Vol. 2, pp.169-80.

Rivlin, G. (2005) 'Green tinge is attracting seed money to ventures', New York Times, 22 June.

Sanders, W.M.G. and Boivie, S. (2004) 'Sorting things out: valuation of new firms in uncertain markets', Strategic Management Journal, Vol. 25, pp.167-186. 
Schein, E.H. (1985) Organisational Culture and Leadership, Jossey-Bass.

Seidl, I. (1993) Ökologie und Innovationen. Die Rolle der Unternehmenskultur in der Agrarchemie, Haupt, Bern.

Sharma, A. (1999) 'Central dilemmas of managing innovation in large firms', California Management Review, Vol. 41, No. 3, pp.146-164.

Siegel, R., Siegel, E. and MacMillan, I. (1988) 'Corporate venture capitalists: autonomy, obstacles, and performance', Journal of Business Venturing, Vol. 3, pp.233-248.

Stone, B. (2003) 'Alternative energy. Venture capitalists are betting on fuel-cell and solar-cell technologies', Newsweek, 17 November.

Stopford, J.M. and Baden-Fuller, C.W.F. (1994) 'Creating corporate entrepreneurship', Strategic Management Journal, Vol. 15, pp.521-536.

Sykes, H.B. (1986) 'The anatomy of a corporate venturing program: factors influencing success', Journal of Business Venturing, Vol. 1, pp.275-293.

Sykes, H.B. (1990) 'Corporate venture capital: strategies for success', Journal of Business Venturing, Vol. 5, pp.37-47.

Sykes, H.B. and Block, Z. (1989) 'Corporate venturing obstacles: sources and solutions', Journal of Business Venturing, Vol. 4, pp.159-167.

Sykes, H.B. and Dunham, D. (1995) 'Critical assumption planning: a practical tool for managing business development risk', Journal of Business Venturing, Vol. 10, pp.413-424.

Tushman, M.L. and Anderson, P. (1986) 'Technological discontinuities and organisational environments', Administrative Science Quarterly, Vol. 31, pp.439-465.

Utterback, J.M. (1994) Mastering the Dynamics of Innovation, Harvard Business School Press, Cambridge, MA.

Von Hippel, E. (1977) 'Successful and failing internal corporate ventures: an empirical analysis', Industrial Marketing Management, Vol. 6, pp.163-174.

Von Rosenstiel, L. (1999) 'Mitunternehmertum - Unterstützung durch unternehmerische Kulturgestaltung', in Wunderer, R.: Mitarbeiter als Mitunternehmer, Neuwied.

Weeks, T. (2004) 'Venture capital going green in 2004', Tornado Insider, 16 April.

Wilson, L. (2003) 'VCs getting ready to come clean: the next big thing could be a clean thing', San Francisco Business Times, 2 May.

Zacharakis, A.L. and Shepherd, D. (2001) 'The nature of information and overconfidence on venture capitalists' decision making', Journal of Business Venturing, Vol. 16, pp.311-332.

\section{Notes}

1 Personal interview, Berkeley, 22 March 2005.

2 www.europeanenergyfair.com

3 www.cleantechventure.com

4 vx.thomsonib.com 